\title{
Exploring the link between market orientation and innovation in the European and US insurance markets
}

\author{
Nora Lado \\ Department of Business Economics, Universidad Carlos III de Madrid, \\ Spain, and \\ Albert Maydeu-Olivares \\ Department of Psychology, University of Barcelona, Spain
}

Keywords Market orientation, Innovation, Global marketing, Insurance companies

\begin{abstract}
Despite the increasing research importance of market orientation in the marketing literature, few comparative studies between the European Union and the USA have been conducted. This limits the understanding of marketing orientation strategy in global markets. Investigates the influence of competitive environments on the uses of market orientation in insurance firms in the EU and the USA and the effects of market orientation on innovations. Using Lambin's conceptualization of market orientation, our results indicate that, although EU and US insurance firms analyze and react to their environment differently, which in turn is reflected in a differential impact on their degree of innovation, this, however, does not translate into overall market orientation differences across markets, differential relations across markets between overall market orientation and innovation degree and innovation performance. Furthermore, there is a positive impact of overall market orientation on insurance firms' innovation degree and innovation performance in both the US and EU markets. The managerial implications of these findings seem clear: the magnitude and the effectiveness of the innovation activities of a firm can be enhanced through the adoption of market orientation principles.
\end{abstract}

\section{Introduction}

There is a growing interest in the concept of market orientation, as empirical evidence shows that companies with higher market orientation obtain better economic and commercial results. Researchers have extensively collected evidence of the positive effect of market orientation on business performance. We have attempted to summarize these empirical results in Table I. However, it is not yet clear why there is such effect and how it operates (Lambin, 1996). The most recent literature suggests that one of the keys to understanding this phenomenon lies in market orientation's positive effect on businesses' degree of innovation (Atuahene-Gima, 1995, 1996; Gatignon and Xuereb, 1997; Han et al., 1998; Hurley and Hult, 1998).

Hurley and Hult (1998) have explicitly provided a theoretical framework linking market orientation, business performance and innovation, drawing on

The assistance of Professor Nicos Scordis (College of Insurance, New York) for the empirical research in the USA is gratefully acknowledged. This research was partially supported by DGESIC, project PB97 0084 


\begin{tabular}{|c|c|c|c|}
\hline Author(s) & Country & Conclusions & \\
\hline Narver and Slater, 1990 & USA & Positive relation $\mathrm{MO} \mathrm{BP}$ & \\
\hline Ruekert, 1992 & USA & Positive relation $\mathrm{MO} \mathrm{BP}$ & \\
\hline Jaworski and Kholi, 1993 & USA & Positive relation $\mathrm{MO} \mathrm{BP}$ & \\
\hline Kholi, Jaworski and Kumar, 1993 & USA & Positive relation MO BP & \\
\hline Diamantopoulos and Hart, 1993 & UK & Mixed results about MO BP relation & \\
\hline Slater and Narver, 1994 & USA & Positive relation $\mathrm{MO} \mathrm{BP}$ & \\
\hline Deng and Dart, 1994 & Canada & Positive relation $\mathrm{MO} \mathrm{BP}$ & \\
\hline $\begin{array}{l}\text { Deshpandé, Farley and Webster, } \\
1993\end{array}$ & Japan & $\begin{array}{l}\text { Positive relation customer orientation } \\
\text { BP }\end{array}$ & \\
\hline Van Bruggen and Smidts, 1995 & The Netherlands & Positive relation $\mathrm{MO} \mathrm{BP}$ & \\
\hline Greenley, 1995 & UK & Positive relation $\mathrm{MO} \mathrm{BP}$ & \\
\hline Lambin, 1996 & Belgium & Positive relation MO BP & \\
\hline Fritz, 1996 & Germany & Positive relation $\mathrm{MO} \mathrm{BP}$ & \\
\hline Pitt, Caruana and Berthon, 1996 & UK, Malta & $\begin{array}{l}\text { Positive relation MO BP in both } \\
\text { countries }\end{array}$ & \\
\hline Selnes, Jaworski and Kohli, 1996 & USA, Scandinavia & Positive relation $\mathrm{MO} \mathrm{BP}$ & \\
\hline Pelham and Wilson, 1996 & USA & Positive relation $\mathrm{MO} \mathrm{BP}$ & \\
\hline Atuahene Gima, 1995, 1996 & Australia & $\begin{array}{l}\mathrm{MO} \text { is an important factor in new } \\
\text { products success }\end{array}$ & \\
\hline Bhuian, 1997 & Saudi Arabia & Non significant relation MO BP & \\
\hline Gatignon and Xuereb, 1997 & USA & $\begin{array}{l}\text { Different strategic orientations have } \\
\text { different impact on innovation } \\
\text { performance according to market } \\
\text { characteristics }\end{array}$ & \\
\hline Greenley and Foxall, 1997, 1998 & UK & $\begin{array}{l}\text { The impact of multiple stakeholder } \\
\text { orientation on performance is } \\
\text { moderated by the external environment }\end{array}$ & \\
\hline Gray et al., 1998 & New Zealand & Positive relation MO BP & \\
\hline Caruana, Pitt and Berthon, 1999 & UK & Non significant relation $\mathrm{MO} B P$ & \\
\hline Avlonitis and Gounaris, 1997 & Greece & Positive relation $\mathrm{MO} \mathrm{BP}$ & \\
\hline $\begin{array}{l}\text { Lado, Maydeu Olivares and Rivera, } \\
1998\end{array}$ & Spain, Belgium & Positive relation $\mathrm{MO} \mathrm{BP}$ & \\
\hline $\begin{array}{l}\text { Kumar, Subramanian and Yauger, } \\
1998\end{array}$ & USA & Positive relation $\mathrm{MO} \mathrm{BP}$ & Table I. \\
\hline Appiah adu, 1998 & Ghana & Positive relation MO BP & Summary of empirical \\
\hline Deshpandé and Farley, 1998 & USA, EU & Positive relation MO BP & research on the \\
\hline Han, Kim and Srivastava, 1998 & USA & Positive relation MO innovation $\mathrm{BP}$ & relationship between \\
\hline Sargeant and Mohamad, 1999 & UK & Non significant relation MO BP & market orientation \\
\hline Baker and Sinkula, 1999 & USA & Positive relation MO BP & (MO) and business \\
\hline Pelham, 2000 & USA & Positive relation MO BP & performance (BP) \\
\hline
\end{tabular}

Slater and Narver's (1995) account of the relationship between market orientation and business performance. According to Slater and Narver (1995) market orientation only improves business performance when it is coupled with a learning orientation. In their own words:

Because of its external emphasis on developing information about customers and competitors, the market driven business is well positioned to anticipate the developing needs of customers and to respond to them through the addition of innovative products and services. This ability gives the market driven business an advantage in the speed and 
effectiveness of its response to opportunities and threats. Thus, a market orientation is inherently a learning orientation (Slater and Narver, 1995, p. 67).

Hurley and Hult (1998) point out that there are two underlying assumptions in Slater and Narver's argument:

(1) market orientation and learning orientation are inherent and inseparable;

(2) a learning orientation mediates the market orientation performance relationship.

Furthermore, they find these assumptions contradictory and that "the apparent contradiction in Slater and Narver's (1995) framework can be resolved by incorporating constructs related to innovation into these models (. . .). We argue that models of market orientation should focus on innovation (implementation of new ideas, products, or processes) rather than learning (...) as the primary mechanism for responding to markets" (Hurley and Hult, 1998, p. 42). Motivated by rather similar arguments, the present investigation examines the relationship between market orientation and business innovation in the European Union (EU) and USA insurance markets.

Market orientation is very important to insurance companies, as with increasing global competition and changes in consumer needs companies have realized that they must stay closer to their markets (Greenwald, 1991). Just as an effective competitive strategy is important to survival in a competitive environment, so is market orientation. From a market orientation viewpoint, the insurance market is of particular interest, as it works with intangible products in which service quality and customer orientation are crucial elements. Yet, little research has been performed in the insurance sector.

This paper focuses on the US insurance market, which is highly relevant due to its size and importance, and on the EU insurance market. The competitive characteristics generated by the EU provide an additional interest to study market orientation in this area. The European insurance sector has traditionally been subject to strict regulations and strong protection from international competition. However, for some years now the European Commission (EC) has been working on the liberalization of this sector and the development of a single European insurance market. According to the insurance experts, there is still a long way to achieve an unrestricted insurance market, although the journey to go to a fully integrated EU and a true single European insurance market is on an inexorable course to fulfilment (Jennings, 1997; Shapiro, 1997). Effective implementation of this has brought about a major increase in competition within the sector and has provoked a major restructuring of insurance companies and groups. Lado et al. (1998) have investigated the market orientation of insurance firms within the EU. These authors have not found significant mean differences in market orientation by country. Furthermore, they report substantial agreement between the factor structures of market orientation across countries. Thus, it seems that the 
European insurance sector can be considered a homogeneous population with respect to market orientation.

For US insurers there is a lot of potential in the EU market. The single European currency (Euro) and the enlargement of the EU present challenging new opportunities to the US insurers (Insurance Advocate, 1997). On the other hand, European insurers are both consolidating domestically and expanding across borders to obtain geographic diversification. European presence in the US insurance industry is not new, but the pace at which US insurance companies have come into ownership by major European insurers has been accelerating. Analysts believe that European life insurance presence in the US could double over the next few years (Friedman, 1999).

The competitive climate in Europe and the USA has also been influenced by changes in consumer behavior. European and US customers now show greater service expectations and less loyalty. As a result, rivalry among competitors is increasing, as is the importance of competitive strategies adapted to this sector's needs. In this background, the degree of orientation towards the customer, distributors, competition and the general socio-economic environment is becoming an increasingly important area of study, not only for academics but also for the business world.

On the other hand, despite the increasing internationalization of firms, and increasing market integration, most of the studies on market orientation confine themselves to domestic markets (with some notable exceptions such as Selnes et al., 1996; Webster, 1994; Pitt et al., 1996). Deshpandé and Webster (1989) have already pointed out the lack of comparative studies between countries. Comparative studies are important, as a nation's character and culture differences as well as political-economic differences can affect the way firms respond to their markets (Porter, 1990). There is a lack of studies providing empirical evidence for the generalizability of domestic markets research to international markets. This is in spite of the fact that sparse replications and extension research have deleterious consequences for the development of a cumulative body of knowledge in the business disciplines (Hubbard et al., 1998).

The present research aims at filling these gaps by evaluating whether the link between market orientation and business innovation could withstand generalization across two large insurance markets (European Union and the USA) with varying political-economic and cultural contexts. Furthermore, if a positive relationship between these two constructs is found, we shall investigate whether this relationship is comparable across markets. This being the primary objective of the present investigation, our research design also will allow us to investigate mean differences across markets in both market orientation and innovation.

\section{Theoretical framework}

Contemporary marketing theory is heavily grounded upon the construct of market orientation. Yet, only recently have operational definitions of market 
orientation been developed (Narver and Slater, 1990; Kohli and Jaworski, 1990). Furthermore, contrary to what one might expect, the essence of the market orientation concept is still an issue under debate. In this theoretical debate, two different approaches seem to prevail one considers market orientation as mainly a company culture, while the other regards it as basically a specific set of behaviors.

Market orientation, as a form of company culture, refers to a specific set of organizational values. In this framework a market-oriented organization places the highest priority on the profitable creation and maintenance of superior customer value (Narver and Slater, 1990; Slater and Narver, 1995). The alternative conceptualization of market orientation, based on its conception as a specific set of behaviors, has been advanced by Kohli and Jaworski (1990). These authors conceptualized market orientation as the implementation of the marketing concept. In their own words:

Market orientation is the organization wide generation of market intelligence pertaining to current and future customer needs, dissemination of the intelligence across departments, and organization wide responsiveness to it (Kohli and Jaworski, 1990, p. 6).

There have been several attempts in the literature to integrate these competing theoretical approaches. For instance, Deng and Dart (1994) have attempted to synthesize these two conceptions of market orientation by defining market orientation as the implementation of a particular business philosophy; the marketing concept. On the other hand, Lambin (1996) and Lado et al. (1998) have defined market orientation as:

A competitive strategy geared to generating and maintaining a situation in which there is a value exchange with [the firms'] markets. The equity in this exchange creates a differentiating position that leads to loyalty to the brand and high economic returns (Lambin, 1996, p. 25).

In their definition of market orientation Lambin (1996) and Lado et al. (1998) expand the concept of market orientation to include distributors, since these constitute the firm's first external client (Day, 1992), and they make products or services available to the final customer (Whiteley, 1991). Likewise, the effects of the environment are also included in the concept of market orientation, since these influence the organizational efficiency and because the firm is an open system that cannot maintain itself. Their definition of market orientation also takes into account that company competitiveness depends on the allocation of human resources and materials to obtain and analyze information on the needs and behavior of market participants. This information is later used to coordinate inter-functional actions for designing and developing plans of action related to market participants. The "analysis" and "strategic actions" components are taken into consideration for each of the four market participants previously described, and are based on the organizational component of "coordination".

In Table II we have attempted to summarize these four different theoretical conceptions of market orientation by listing their respective components. In 


\begin{tabular}{|c|c|}
\hline Authors & Components of market orientation \\
\hline \multirow[t]{3}{*}{ Kohli and Jaworski (1990) } & Generation of market intelligence \\
\hline & Dissemination of market intelligence \\
\hline & Entire organization's capacity to respond \\
\hline \multirow[t]{2}{*}{ Narver and Slater (1990) } & Customer oriented \\
\hline & Competitor oriented \\
\hline \multirow{4}{*}{ Deng and Dart (1994) } & $\begin{array}{l}\text { Inter functional coordination } \\
\text { Customer oriented }\end{array}$ \\
\hline & Competitor oriented \\
\hline & Inter functional coordination \\
\hline & Profit oriented \\
\hline Lambin (1996) and & Information gathering and analysis on: \\
\hline \multirow[t]{9}{*}{ Lado, Maydeu Olivares and Rivera (1998) } & - final customers \\
\hline & - distributors \\
\hline & - competitors \\
\hline & - environment \\
\hline & Inter functional coordination \\
\hline & Strategic actions on: \\
\hline & - final customers \\
\hline & $\begin{array}{l}\text { - distributors } \\
\text { - competitors }\end{array}$ \\
\hline & - environment \\
\hline
\end{tabular}

Table II.

Alternative conceptions of market orientation

this paper we shall use Lambin's (1996) conceptualization of market orientation.

Little is known about how market orientation changes to accommodate different cultural environments within an economic sector. As can be seen in Table II, only Lambin's (1996) conceptualization of market orientation explicitly takes into account environmental factors. It is difficult to compare the US and EU insurance markets with regard to their orientation to their distributors and clients. European firms have outdistanced their US peers in some areas, particularly bancassurance (i.e. the successful delivery of life and non-life insurance products through banking channels). In spite of this, however, though fragmentary, current evidence supports the widespread view that US financial service firms lead their European peers in most dimensions of the retail delivery revolution. According to a Bank Management article (Davis, 1995), it appears that leading US firms have invested more heavily in branch automation, branch network segmentation and software needed to develop useful customer information. Thus, within Lambin's (1996) theoretical framework, our first hypothesis is:

H1: US insurance firms show a higher degree of environmental analysis and a higher number of targeted actions than their EU counterparts.

It is hard to hypothesize a priori whether further mean differences are expected between US and EU insurance firms in the remaining components of Lambin's conceptualization of market orientation. Nevertheless, it is difficult to foresee whether the expected mean differences in the environmental components of the 
model will result in an overall mean difference in market orientation. Thus, by parsimony we hypothesize that:

H2: There are no mean differences between US and EU insurance firms in the components of the model involving customers, distributors and competitors, nor in interfunctional coordination.

H3: There are no overall mean differences in market orientation between US and EU insurance firms.

Interesting as it may be to contrast these hypotheses, the main objective of the present investigation is to explore whether these mean differences translate into differential relations between market orientation and innovation, as according to Hurley and Hult (1998) this may be the key dimension that explains the recurrent empirical findings linking market orientation to superior business performance.

Within Slater and Narver's (1995) framework, innovation is one of the "core value-creating capabilities" that drives MO-performance association. Han et al. (1998) have recently provided empirical evidence supporting the view that market orientation positively influences the organization's innovativeness. However, why is this so? Is it because market oriented firms are able to develop and introduce more new product/services to the market and/or is it because of its greater general effectiveness in innovation activities? Han $e t$ al. do not distinguish between a company's degree of innovation and its degree of new product success, and hence they do not address this issue. The contribution of innovation to corporate survival and growth is an accepted notion but aggressive rates of products' introductions are not always associated with successful product/service innovation (Manu and Sriram, 1996). Calantone et al. (1994) do distinguish between the constructs of degree of innovation and of innovation success and examine the relationship between the two. According to these authors innovation performance or the degree of success refers to the level at which new products/ services meet their commercial and financial objectives. Innovation degree, on the other hand, is defined as a "holistic construct based on several factors, such as the rate of new product launch and the rate of improvements in the production or rending service". Rather interestingly, Calantone et al. (1994) found the empirical relationship between these constructs to be non-significant. Hence, these two phenomena appear to be distinct. In this research we shall assess the level of innovation degree and innovation performance of US and EU insurance firms. Again, there does not seem to be any theoretical or empirical result that suggests differential levels of innovation across markets in this sector. Therefore, by parsimony we formulate the following hypothesis:

H4: There are no mean differences in innovation degree and innovation performance between US and EU insurance firms.

Also, if we take market orientation to be the generation of market intelligence (i.e. ascertaining current and future customer needs and monitoring competitors and environmental factors), it follows that market orientation is a 
source of ideas for new products and services and that it should therefore positively affect the degree of innovation in companies. At the same time, the market-oriented firm's greater understanding of its market environment should also reduce the incidence of new product failures (Cooper, 1994; Ottum and Moore, 1997). For instance, in a recent study, Song and Parry (1996), using data on 788 new products introduced by 404 Japanese firms, examined the links between new product performance and several factors. Their findings clearly support the importance of market understanding for the success of new products. Also, in their cross-national research on the controllable factors of new product performance, Calantone $e$ t al. (1996) concluded that:

It is important to collect and assess market and competitive information in order to understand customers' needs, wants and specifications for the product (. . .), to understand customers' purchase decisions, and to learn about competitors' strategies ... . (p. 341).

Given that market orientation provides enhanced knowledge of customers' preferences and wants and enables companies to adapt better to these wants, we formulate the following two hypotheses concerning insurance companies in the EU and US markets:

H5: Firms' market orientation is positively related to their innovation degree.

H6: Firms' market orientation is positively related to their innovation performance.

Furthermore, from our previous discussion on differential levels of environmental focus between US and EU insurance firms, we hypothesize that:

H7: There are differential relations between environmental components of market orientation and innovation degree and performance between US and EU insurance firms.

\section{Methodology and measurement}

Since the constructs of interest are not directly observable, a series of indicators was used for each target construct. The measures of these constructs were developed in several stages. First, based on the defined constructs, preliminary measures were adopted from the existing literature. Then, in a second stage, we submitted a list of the defined constructs and measures to a panel of six marketing, service operations management, and strategic management academicians, with acknowledged expertise in the insurance service field. Three of these experts were familiar with the US insurance field, and the remaining three with the EU insurance field. Given a definition of the constructs we intended to measure, all our experts concluded that our instruments were valid measures of the theoretical constructs under consideration. Finally, in a third stage, a pretest was conducted in both markets among three executives from three selected insurance firms:

- Market orientation. We used a questionnaire designed by Lado et al. (1998) to measure the market orientation of insurance companies in 
Belgium and Spain and this has been found to be valid and reliable. Their questionnaire was based on a preliminary set of items designed by Lambin (1996). The questionnaire consists of 30 items, yielding a score for each of the nine components of their definition of market orientation, and an overall market orientation score. Each item was presented as a statement representing the ideal behavior of a market-oriented company. A scale from 0 to 10 was used for these items, where 0 indicated that the statement "was entirely untrue" of the firm, 5 that it was "more or less true" and 10 that "it was entirely true".

- Innovation degree. We used the widely used scale developed by Miller and Friesen (1982). This is a Likert scale comprising three items. A seven-point scoring format was employed for these items.

- Innovation performance. We used the four-item scale developed by Atuahene-Gima (1996). Here, the respondent is asked to choose a new product/service that the company has introduced within the last five years (a new product is defined as an improved product, the expansion of a product line or a totally new product). This new product is used as a reference to assess the degree of achievement of objectives set for new products in terms of sales, market share, sales growth and profits using a seven-point Likert scale.

\section{Sample}

A questionnaire was mailed to the managing directors of insurance companies that sold personal insurance with a domestic market quota greater than 0.05 per cent in either the US or the EU markets. Although previous studies (see Narver and Slater, 1990) used responses from SBU managers, we chose only corporate level managers and CEOs/managing directors, because top management involvement is vital to implementing market orientation (Kohli and Jaworski, 1990; Deshpandé et al., 1993), and it is the responsibility of corporate level executives (Webster, 1994).

The survey yielded 211 valid questionnaires, 137 from the EU and 74 from the USA. In order to assess the possibility of non-response bias, the questionnaires were divided into quartiles on the basis of reception date (Armstrong and Overton, 1977). Early-late respondents comparisons revealed non-significant non-response bias.

\section{Results}

Before we can proceed to investigate our main hypotheses, we must assess whether the questionnaires yielded reliable results across populations. The reliability estimates we obtained are shown in Table III. As can be seen, all subscales and scales showed adequate reliability across populations. The lowest reliability estimate was 0.62 for the Distributor Targeted Actions subscale in the USA.

We next examined whether there were mean differences across populations in any market orientation component or in innovation. The results are shown in 


\begin{tabular}{|c|c|c|c|c|}
\hline Scale & No. of items & $\begin{array}{l}\text { ach's } \alpha \\
\text { Europe }\end{array}$ & USA & \\
\hline Market orientation & 30 & 0.95 & 0.91 & \\
\hline Customer analysis & 5 & 0.85 & 0.82 & \\
\hline Customer targeted actions & 3 & 0.71 & 0.71 & \\
\hline Distributor analysis & 5 & 0.86 & 0.86 & \\
\hline Distributor targeted actions & 3 & 0.73 & 0.62 & \\
\hline Competitor analysis & 3 & 0.87 & 0.78 & \\
\hline Competitor targeted actions & 2 & 0.79 & 0.73 & \\
\hline Environment analysis & 2 & 0.84 & 0.75 & \\
\hline Environment targeted actions & 2 & 0.77 & 0.84 & \\
\hline Interfunctional coordination & 5 & 0.82 & 0.87 & \\
\hline $\begin{array}{l}\text { Innovation degree } \\
\text { Innovation performance }\end{array}$ & $\begin{array}{l}3 \\
4\end{array}$ & $\begin{array}{l}0.71 \\
0.91\end{array}$ & $\begin{array}{l}0.76 \\
0.94\end{array}$ & $\begin{array}{r}\text { Table III. } \\
\text { Reliability estimates } \\
\text { across markets }\end{array}$ \\
\hline
\end{tabular}

Table IV. As can be seen in this Table, we found significant differences at $\alpha=$ 0.01 only in the market orientation components directly related to their market environment, with US insurance companies reporting higher levels of environment analysis and environment targeted actions. This, however, does not translate to higher overall levels of market orientation. Hence, we obtained empirical support for $H 1, H 2$ and $H 3$. No significant differences at this significance level were found for the spread of these measures. Furthermore, no significant mean differences across populations were found in innovation degree and innovation performance, thus supporting $H 4$.

Next, we examined the correlations between firms' market orientation and their levels of innovation degree and innovation performance across markets. As can be seen in Table V, in EU insurance firms, all market orientation components are significantly related to the firms' degree of innovation and their innovation performance. In contrast, in US insurance firms, none of the analysis components

\begin{tabular}{|c|c|c|c|c|c|c|c|}
\hline \multirow[b]{2}{*}{ Variable } & \multicolumn{2}{|c|}{ Europe } & \multicolumn{2}{|c|}{ USA } & \multirow[b]{2}{*}{$t$} & \multirow[b]{2}{*}{ Sig } & \\
\hline & $x$ & std & $x$ & std & & & \\
\hline Market orientation & 6.19 & 1.45 & 6.58 & 1.15 & 1.10 & 0.30 & \\
\hline Customer analysis & 5.64 & 1.90 & 5.89 & 1.85 & 0.85 & 0.36 & \\
\hline Customer targeted actions & 6.21 & 1.76 & 6.45 & 1.86 & 0.86 & 0.36 & \\
\hline Distributor analysis & 6.64 & 1.72 & 6.86 & 1.47 & 0.80 & 0.37 & \\
\hline Distributor targeted actions & 7.00 & 1.84 & 7.54 & 1.61 & 4.30 & 0.04 & \\
\hline Competitor analysis & 6.30 & 1.91 & 6.17 & 1.74 & 0.22 & 0.64 & \\
\hline Competitor targeted actions & 6.05 & 2.07 & 5.88 & 1.86 & 0.36 & 0.55 & \\
\hline Environment analysis & 6.08 & 2.08 & 7.15 & 1.95 & 13.06 & $<0.01$ & \\
\hline Environment targeted actions & 5.51 & 2.39 & 6.63 & 2.10 & 11.15 & $<0.01$ & Table IV. \\
\hline Interfunctional coordination & 6.36 & 1.92 & 6.66 & 1.93 & 1.08 & 0.30 & $\begin{array}{l}\text { Means, standard } \\
\text { deviations, and mean }\end{array}$ \\
\hline Innovation degree & 14.14 & 2.92 & 12.50 & 4.17 & 2.88 & 0.01 & comparisons across \\
\hline Innovation performance & 19.57 & 5.78 & 19.12 & 6.70 & 0.47 & 0.64 & markets \\
\hline
\end{tabular}




\begin{tabular}{|c|c|c|c|c|c|}
\hline & \multirow[b]{2}{*}{ Variable } & \multicolumn{2}{|c|}{ Europe } & \multicolumn{2}{|c|}{ USA } \\
\hline & & $\begin{array}{c}\text { Innovation } \\
\text { degree }\end{array}$ & $\begin{array}{l}\text { Innovation } \\
\text { performance }\end{array}$ & $\begin{array}{l}\text { Innovation } \\
\text { degree }\end{array}$ & $\begin{array}{l}\text { Innovation } \\
\text { performance }\end{array}$ \\
\hline & Market orientation & 0.57 & 0.58 & 0.41 & 0.55 \\
\hline & Customer analysis & 0.48 & 0.42 & $0.24 *$ & 0.43 \\
\hline & Customer targeted actions & 0.53 & 0.53 & 0.30 & 0.57 \\
\hline & Distributor analysis & 0.40 & 0.48 & 0.29 & 0.30 \\
\hline & Distributor targeted actions & 0.37 & 0.42 & 0.47 & 0.30 \\
\hline & Competitor analysis & 0.43 & 0.35 & $0.19 *$ & $0.10^{*}$ \\
\hline & Competitor targeted actions & 0.33 & 0.43 & 0.42 & 0.34 \\
\hline & Environment analysis & 0.45 & 0.45 & $0.11 *$ & 0.35 \\
\hline & Environment targeted actions & 0.42 & 0.33 & $0 *$ & 0.32 \\
\hline $\begin{array}{l}\text { Table V. } \\
\text { Correlations between }\end{array}$ & Interfunctional coordination & 0.44 & 0.49 & 0.30 & 0.37 \\
\hline
\end{tabular}

Correlations between market orientation and innovation
Notes: All correlations are significant $(\phi<0.05)$ except those marked as *; the correlations marked in bold are significantly different $(\phi<0.01)$ across populations

of Lambin's (1996) model (i.e. customer analysis, competitor analysis, and environmental analysis) is related to the firms' degree of innovation. Furthermore, US insurance firms' environmental targeted actions are not related to their innovation degree, nor is their competitors' analysis related to their innovation performance. In spite of this, overall market orientation is significantly related to both innovation degree and innovation performance across populations. Thus, we obtain partial support for $H 5$ and $H 6$.

To quantify the observed trends in Table $\mathrm{V}$ that suggest differential correlations between market orientation and innovation across populations, we tested equality constraints among the observed correlations (Steiger, 1990). The results are also shown in Table V. Again, we found significant differences across markets at $\alpha=0.01$ only in the associations between environmental market orientation components and innovation, with US insurance companies reporting a lower association between innovation degree and environment analysis and environment targeted actions. This, however, did not result in a lower association between overall market orientation and innovation degree. No significant correlation differences between market orientation components and innovation performance were found.

\section{Discussion}

Our empirical findings provide relevant insights regarding the generalization across the EU and US insurance market of both the concept of market orientation and its influence on business innovation. Our key results can be summarized as follows:

(1) Market orientation, innovation degree and innovation performance can be reliably and validly measured across EU and US insurance firms.

(2) There are no mean differences between US and EU insurance firms in their innovation degree or in their innovation performance. 
(3) US insurance firms show a higher degree of environmental analysis and environmental actions than their EU counterparts. These differences, however, are not so substantial as to result in higher overall levels of market orientation.

(4) Despite (3), EU insurance firms' environmental analysis and environmental actions translate into higher levels of innovation, whereas US insurance firms' environmental analysis and actions do not translate into higher levels of innovation. Again, these differential relations are not so substantial as to result in differential associations across EU and US firms between market orientation and innovation.

(5) Overall market orientation is significantly related to innovation degree and innovation performance in both the EU and US insurance markets.

Our research findings expand earlier empirical studies that focused on identifying market orientation and its configuration. We defined market orientation as the behaviors of the firms that routinely and systematically analyze and use information about its stakeholders to coordinate and implement strategic actions. Hence, our theoretical model of market orientation expands this construct's traditional definitions by integrating the distributor orientation and the environment orientation. US companies seem to significantly devote more efforts to analyze their environment and to implement environment-focused strategic actions. However, European firms' environmental analysis and actions significantly translate into higher levels of innovation degree, whereas US firms' environmental efforts do not. This is a surprising finding that requires further exploration, and which we are currently looking into in further depth. We would like to point out that this finding was made possible by our use of a broader conceptualization of market orientation that includes environmental aspects. Note, however, that, relevant as this finding may be, we did not find significant differences in overall market orientation, nor in their spread, nor in its relationship to innovation degree and performance across markets. This empirical finding should be emphasized, as meaningful comparisons across different contexts or cultures require that the measures are functionally equivalent.

Furthermore, our measure of market orientation was found to be valid and reliable across markets, which indicates that our scale is meaningful across cultural differences. This is critical information for managers who must cope with international competition. It assures them that their market strategies can maintain normal competitiveness, even though countries and markets vary. However, further research along these lines in other economic sectors is clearly needed.

In closing, the empirical findings presented in this article provide relevant insights regarding the generalization across both the EU and US insurance markets of the concept of market orientation and in its influence on business innovation. We found a statistically significant positive association between market orientation and business innovation. Previous studies support the view that stressing a market orientation leads to innovation improvements (for example, Han et al., 1998) but in line with Calantone et al. (1994) our study 
examined two important dimensions of business innovation (degree of innovation and innovation performance) and has shown that a market orientation emphasis improves both. More market oriented insurance firms are more innovative and have higher innovation success. This finding supports prior empirical research, which suggests that the predominant sources of ideas for new products in the financial service sector are the marketing activities, especially the customers, and an analysis of the competitors (Davison et al., 1989). In addition, an investigation of over 600 new product launches in the financial service industry concluded that a critical success factor that distinguished the top performers in new products/ services was having a market-oriented new product process (Cooper and Edgett, 1996). The managerial implications of these findings seem clear: the magnitude and the effectiveness of the innovation activities of a firm can be enhanced through the adoption of market orientation principles.

\section{References}

Appiah adu, K. (1998), "Market orientation and performance", Journal of Strategic Marketing, No. 6, pp. 2545.

Armstrong, J.S. and Overton, T. (1977), "Estimating non response bias in mail surveys", Journal of Marketing Research, Vol. 14, August, pp. 396402.

Atuahene Gima, K. (1995), "An exploratory analysis of the impact of market orientation on new product performance”, Journal of Product Innovation Management, Vol. 12, pp. 27593.

Atuahene Gima, K. (1996), "Market orientation and innovation”, Journal of Business Research, No. 35, pp. 93103.

Avlonitis, G. and Gounaris, S. (1997), "Marketing orientation and company performance: industrial vs. consumer goods companies”, Industrial Marketing Management, No. 26, pp. 385402.

Baker, W. and Sinkula, J. (1999), "The synergistic effect of market orientation and learning orientation on organizational performance", Journal of the Academy of Marketing Science, Vol. 27 No. 4, pp. 41127.

Bhuian, S. (1997), "Exploring market orientation in banks: an empirical examination in Saudi Arabia”, The Journal of Service Marketing, Vol. 11 No. 5, pp. 31728.

Calantone, R., di Benedetto, C. and Bhoovaraglaran, S. (1994), "Examining the relationship between degree of innovation and new product success", Journal of Business Research, No. 30, pp. 1438 .

Calantone, R., Schmidt, J. and Song, M. (1996), "Controllable factors of new product success: a cross national comparison”, Marketing Science, Vol. 15 No. 4, pp. 34158.

Caruana, A., Pitt, L. and Berthon, P. (1999), "Excellence market orientation link: some consequences for service firms", Journal of Business Research, No. 44, pp. 515.

Cooper, R. and Edgett, S. (1996), "Critical success factors for new financial services", Marketing Management, Fall, pp. 2637.

Cooper, R.C. (1994), "New product: the factors that drive success", International Marketing Review, Vol. 11 No. 1, pp. 6076.

Davis S. (1995), "The delivery of retail financial service: lessons from Europe", Bank Management, Vol. 71 No. 6, November/December, p. 60.

Davison, H., Watkins, T. and Wright, M. (1989), "Developing new personal financial products: some evidence of the role of market research", Vol. 7 No. 1, pp. 815.

Day, G. (1992), "Marketing's contribution to the strategy dialogue", Journal of the Academy of Marketing Science, Vol. 20, Fall, pp. 3239. 
Deng, S. and Dart, J. (1994), "Measuring market orientation: a multi factor, multi items approach", Journal of Marketing Management, No. 10, pp. 72542.

Deshpandé, R. and Farley, J. (1998), "Measuring market orientation: generalization and synthesis", Journal of Market Focused Management, Vol. 2 No. 3, pp. 21332.

Deshpandé, R. and Webster, F. (1989), "Organizational culture and marketing: defining the research agenda”, Journal of Marketing, No. 43, January, pp. 315.

Deshpandé, R., Farley J. and Webster, F. (1993), “Corporate cultures, customer orientation, and innovativeness in Japanese firms: a quadrad analysis", Journal of Marketing, January, No. 57, pp. 237.

Diamantopoulos, A. and Hart, S. (1993), "Linking market orientation and company performance: preliminary evidence on Kohli and Jaworski's framework”, Journal of Strategic Marketing, No. 1, pp. 93121.

Friedman, A. (1999), “The Europeans are coming!”, Life Association News, Vol. 94 No. 4, April, pp. 247.

Fritz, W. (1996), "Market orientation and corporate success: findings from Germany", European Journal of Marketing, Vol. 30 No. 8, pp. 5974.

Gatignon, H. and Xuereb, J. (1997), "Strategic orientation of the firm and new product performance”, Journal of Marketing Research, Vol. 34, February, pp. 7790.

Gray, B., Matear, S. and Boshoff, C. (1998), "Developing a better measure of market orientation”, European Journal of Marketing, Vol. 32 No. 9/10, pp. 884903.

Greenley, G. (1995), "Market orientation and company performance: empirical evidence from the UK", British Journal of Management, No. 6, pp. 113.

Greenley, G. and Foxall, G. (1997), "Multiple stakeholder orientation in UK companies and the implications for company performance", Journal of Management Studies, Vol. 34 No. 2, pp. 25984.

Greenley, G. and Foxall, G. (1998), "External moderation of association among stakeholder orientation and company performance", International Journal of Research in Marketing, No. 15 , pp. 5169.

Greenwald, J. (1991), “World insurance congress: global insurers told to put customers firths", Business Insurance, Vol. 25 No. 8, pp. 34.

Han, J., Kim, N. and Srivastava, R. (1998), "Market orientation and organizational performance: is innovation the missing link?”, Journal of Marketing, Vol. 62, October, pp. 3045.

Hubbard, R., Vetter, D. and Little, E. (1998), "Replication in strategic management: scientific testing for validity, generalizability and usefulness", Strategic Management Journal, Vol. 19 No. 3, pp. 24354.

Hurley, R. and Hult, T. (1998), "Innovation, market orientation and organizational learning: an integration and empirical examination”, Journal of Marketing, Vol. 62, July, pp. 4254.

Insurance Advocate (1997), Business \& Financial Section, Vol. 107 No. 25, 21 June, p. 28.

Jaworski, B. and Kohli, A. (1993), "Market orientation: antecedents and consequences", Journal of Marketing, Vol. 57, July, pp. 5370.

Jennings, J. (1997), "European Union integration seen as anything but smooth", National Underwriter, Property \& Casualty/Risk \& Benefits Management, Vol. 101 No. 20, pp. 6983.

Kohli, A. and Jaworski, B. (1990), "Market orientation: the construct, research propositions, and managerial implications", Journal of Marketing, Vol. 54, April, pp. 118.

Kohli, A., Jaworski, B. and Kumar, A. (1993), "MARKOR: A measure of market orientation”, Journal of Marketing Research, Vol. 30, November, pp. 46777.

Kumar, K., Subramanian, R. and Yauger, Ch. (1998), "Examining the market orientation performance relationship: a context specific study”, Journal of Management, Vol. 24 No. 2, pp. 20133. 
Lado, N., Maydeu Olivares, A. and Martinez (1998), "The relationship between market orientation and service innovation in the insurance business: a Spanish investigation", International Journal of Management, Vol. 16 No. 3, pp. 37485.

Lado, N., Maydeu Olivares, A. and Rivera, J. (1998), "Measuring market orientation in several populations: a structural equations approach”, European Journal of Marketing, Vol. 32 No. 1/2, pp. 2339.

Lambin, J. (1996), "The misunderstanding about marketing, today; marketing is too important to be left to sole marketing function. An empirical study in the private insurance sector", CEMS Business Review, Vol. 1 No. 1 2, pp. 3756.

Manu, F. and Sriram, V. (1996) "Innovation, marketing strategy, environment, and performance", Journal of Business Research, No. 35, pp. 7991.

Miller, D. and Friesen, P. (1982), "Innovation in conservative and entrepreneurial firms: two models of strategic momentum”, Strategic Management Journal, Vol. 3, pp. 125.

Narver, J. and Slater, S. (1990), "The effect of a market orientation on business profitability", Journal of Marketing, Vol. 54, October, pp. 2035.

Ottum, B. and Moore, W. (1997), "The role of market information in new product success/failure", Journal of Product Innovation Management, Vol. 14, pp. 25873.

Pelham, A. (2000), "Market orientation and other potential influences on performance in small and medium sized manufacturing firms", Journal of Small Business Management, Vol. 38 No. 1, pp. 4867.

Pelham, A. and Wilson, D. (1996), "A longitudinal study of the impact of market structure, firm structure, strategy, and market orientation culture on dimensions of small firm performance", Journal of the Academy of Marketing Science, Vol. 24 No. 1, pp. 2743.

Pitt, L., Caruana, A. and Berthon, P. (1996), "Market orientation and business performance: some European evidence", International Marketing Review, Vol. 13 No. 1, pp. 518.

Porter, M. (1990), The Competitive Advantage of Nations, The Free Press, New York, NY.

Ruekert, R. (1992), "Developing a market orientation: an organizational strategy perspective", International Journal of Marketing, Vol. 9, pp. 22545.

Sargeant, A and Mohamad, M. (1999), "Business performance in the UK hotel sector does it pay to be market oriented?”, The Service Industry Journal, Vol. 19 No. 3, pp. 4259.

Selnes, F., Jaworski, B. and. Kohli, A. (1996), "Market orientation in United States and Scandinavian companies: a cross cultural study”, Scandinavian Journal of Management, Vol. 12 No. 2, pp. 13957.

Shapiro, S. (1997), “Open EU market still in the works”, Business Insurance, Vol. 31 No. 1, pp. 236.

Slater, S. and Narver, J. (1994), "Does competitive environment moderate the market orientation performance relationship?”, Journal of Marketing, Vol. 58, January, pp. 4655.

Slater, S. and Narver, J. (1995), "Market orientation and the learning organization", Journal of Marketing, Vol. 59, July, pp. 6374.

Song, M. and Parry, M. (1996), "What separates Japanese new products winners form losers", Journal of Product Innovation Management, Vol. 13, pp. 42239.

Steiger, J. (1990), "Tests for comparing elements of a correlation matrix", Psychological Bulletin, No. 87, pp. 24551.

Van Bruggen, G. and Smidts, A. (1995), "The measurement of market orientation: a promising tool for management?", Proceedings CEMS Academic Conference, April, Vienna.

Webster, F. Jr (1994), Market driven Management, John Wiley \& Sons Inc., New York, NY.

Whiteley, R. (1991), The Customer Driven Company, Addison Wesley Publishing Co., Inc., Reading, MA. 